\title{
Growth of filter-feeding benthic invertebrates from a region with variable upwelling intensity
}

\author{
Nicole E. Phillips* \\ Department of Ecology, Evolution and Marine Biology, University of California at Santa Barbara, Santa Barbara, \\ California 93106, USA
}

Present address: School of Biological Sciences, PO Box 600, Victoria University of Wellington, Wellington, New Zealand

\begin{abstract}
Coastal upwelling is an ocean feature thought to have important impacts on benthic marine communities by enhancing planktonic productivity in the nearshore environment. In this study, growth rates of 3 species of filter-feeders were examined over a geographic region that includes sites where upwelling is typically weak (south of Point Conception, California, USA) and sites where upwelling is often strong and frequent (at and to the north of Point Conception). The growth of the mussel Mytilus californianus, the gooseneck barnacle Pollicipes polymerus and the acorn barnacle Balanus glandula, as well as the body condition of $M$. californianus, were all up to 3-6 times higher at sites furthest south of Point Conception, and decreased dramatically moving north around the point. Spatial variation in food availability (measured as chlorophyll $a$, particulate organic carbon and particulate organic nitrogen) and food quality (measured as $\mathrm{C} / \mathrm{N}$ ratios) did not explain these patterns of growth. Tidal height of the organisms also failed to account for persistent spatial variation in growth rates. Water temperature varied in a pattern consistent with growth rates (i.e. mean temperatures were warmer in the south), and was the one factor most often selected in stepwise regressions for models contributing to patterns of filter-feeder growth. This study suggests that factors other than, or in conjunction with, productivity may drive large-scale differences in benthic filter-feeder growth rates.
\end{abstract}

KEY WORDS: Marine invertebrates · Rocky intertidal $\cdot$ Filter-feeding $\cdot$ Growth rates $\cdot$ Upwelling Benthic-pelagic coupling $\cdot$ Mussels $\cdot$ Barnacles

\section{INTRODUCTION}

Historically, marine ecologists have focused on the roles of biotic interactions (e.g. competition, predation, grazing, commensalisms) and physical stresses (e.g. wave exposure, stress from heat or desiccation) in structuring populations and communities of benthic organisms, operating on a relatively local scale (e.g. Lewis 1964, review by Connell 1972, Stephenson \& Stephenson 1972, Menge 1992). More recently, researchers have turned their interests to understanding factors influencing population dynamics and community structure over larger scales and have begun to explicitly examine the role of oceanographic processes and physical features on benthic, coastal organisms
(Bustamante et al. 1995, Menge et al. 1997a,b, Menge 2000, Broitman et al. 2001).

One feature garnering particular attention is coastal upwelling. Cycles of upwelling and relaxation (when winds weaken) can concentrate and transport larvae to shore (Roughgarden et al. 1988, Wing et al. 1995, Shanks et al. 2000). Because the high nutrients in upwelled water can also stimulate phytoplankton productivity, it has been hypothesized that upwelling and relaxation cycles can also deliver planktonic food to adult benthic filter-feeders, and this may positively influence their growth in the same region where the upwelling occurs (Menge 1992, Menge et al. 1997a,b). However, hydrographic processes are complex and phytoplankton blooms resulting from upwelled water 
may not be transported back to shore in the same region the upwelling occurred, but instead be delivered further downcurrent (Wieters et al. 2003).

In central California, USA, Point Conception is a major boundary separating distinct water masses (Sverdrup 1938). Upwelling is a strong and frequent feature at Point Conception (Brink et al. 1984, Atkinson et al. 1986) and to the north, with resultant offshore phytoplankton blooms in the nutrient-rich water (Abbott \& Zion 1985, Pelaez \& McGowan 1986). South of Point Conception, in the Santa Barbara Channel, upwelling is generally weak and sporadic (Hickey 1993).

Although Point Conception is the northern or southern biological range limit for many benthic species, many others have ranges that span Point Conception, including dominant intertidal species like the mussel Mytilus californianus, the gooseneck barnacle Pollicipes polymerus and the acorn barnacle Balanus glandula, which are common both north and south of the point. These 3 species also overlap in their distribution within a site, occupying the mid-zone of the intertidal. Because they are sessile and filter food from the plankton, they are potential competitors for both space and resources. Since these 3 species capture plankton by different mechanisms, they also may respond distinctly to changes in the composition of the plankton.

Because mussels and barnacles are common and abundant, share similar sessile lifestyles, and frequently have strong ecological interactions, they are useful species to examine the potential impacts of regional variation in upwelling on coastal organisms. One of the likely responses to variation in upwelling is differential growth rates. Variation in growth rates among populations of interacting species may greatly alter the nature of community structure and dynamics (Bertness et al. 1991), because vulnerability to physical stress (Vermeij 1971), competition (Buss 1986) and predation (Paine 1976) can all be size-dependent.

Herein, I examine spatial variation in growth rates and potential underlying causes across the region spanning Point Conception. Some predictions for this system are: (1) if the upwelling that is frequent north of Point Conception results in the onshore delivery of higher phytoplankton to northern sites than to those to the south, mussel growth rates may be higher in the northern region; (2) as mainly zooplanktivores, barnacle growth rates may be decoupled from those of mussels, and not related to phytoplankton biomass; (3) if filter-feeders are more dependent on particulates than phytoplankton (as postulated by Cliff 1982b for False Bay, South Africa), then filter-feeder growth rates across the entire region may be more correlated with variability in particulate organic carbon than in phytoplankton.

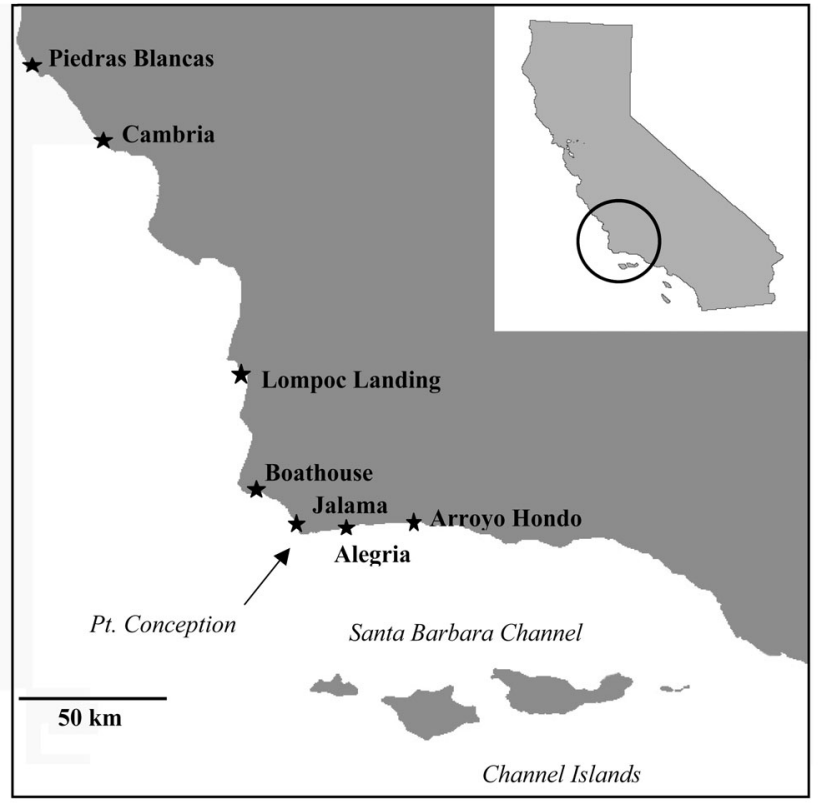

Fig. 1. Experimental intertidal sites in southern and central California, USA

\section{MATERIALS AND METHODS}

Growth experiments. I conducted 2 studies, 1 in spring (mid-February to early June) and 1 in summer (mid-May to end of September) 2000, to quantify growth of the sea mussel Mytilus californianus and the gooseneck barnacle Pollicipes polymerus at 7 sites spanning Point Conception: Piedras Blancas, Cambria, Lompoc Landing, Boathouse, Jalama, Alegria, and Arroyo Hondo (Fig. 1). Additionally, for summer only, I measured growth for naturally settling acorn barnacles Balanus glandula at 5 of the same sites (excluding Cambria and Boathouse because no settlement occurred there).

Mussels: For the spring study, several hundred mussels were collected (range of initial sizes: 33 to $57 \mathrm{~mm}$, mean $\pm \mathrm{SD}=44.9 \pm 4.74 \mathrm{~mm}$ ) from a site near the University of California Santa Barbara campus. I made a small notch in the outer margin of each shell, and then outplanted the mussels to the sites within a few days of initial collection (new growth was measured from this notch when mussels were recollected 4 mo later); 4 plots of 25 mussels each were outplanted to bare rock in the mid-zone at each site. Each plot of mussels was initially held in place for several weeks by plastic mesh, which was removed after the byssal threads had reattached to the rock. Dry body weights were obtained after dissecting out all the flesh from each individual and drying to a constant weight. The same methods were used for the summer growth study (midMay to end of September; range of initial sizes: 34.6 to $54.1 \mathrm{~mm}$, mean $\pm \mathrm{SD}=43.9 \pm 3.97 \mathrm{~mm})$. 
Gooseneck barnacles: For the spring study, small chunks of rock with small clumps of young gooseneck barnacles were chiseled out of the intertidal from Ellwood, and outplanted to all the sites with marine epoxy. For identification purposes, numbered insect tags were glued to the tergum plate on the smaller sized individuals in each clump. The distance between the rostral and carinal plates (RC length) of each tagged individual was measured using calipers (initial RC length: 7.3 to $14.2 \mathrm{~mm}$, mean $\pm \mathrm{SD}=11.1 \pm 1.6$ ). This distance has been used as an index of growth in gooseneck barnacles in previous studies (Paine 1974, Lewis \& Chia 1981). Clump size varied, so the number of clumps outplanted to each site (4 to 11) was chosen to achieve a total of 50 to 60 tagged barnacles per site. Because several outplanted clumps were lost due to marine epoxy failure, for the summer study small individuals were tagged and measured in situ from multiple clumps at each site (initial RC length: 6.6 to $15.4 \mathrm{~mm}$, mean $\pm \mathrm{SD}=10.4 \pm 1.99$ ).

Acorn barnacles: To measure acorn barnacle growth, 5 ceramic plates were bolted into the rocky substrate of the mid-zone at each site beginning at the end of April 2000. An array of small, shallow pits was drilled into the smooth surface of each plate to facilitate settlement and ensure that barnacles were able to grow solitarily. Every 2 wk the plates were photographed during aerial exposure at low tide from a fixed distance and orientation. Using image analysis, individual barnacles were identified and the basal diameter measured. Growth rates were calculated as the increase in basal diameter $\left(\mathrm{mm} \mathrm{d}^{-1}\right)$ after approximately $70 \mathrm{~d}$ of growth.

Environmental characteristics of sites. Food availability: To characterize food availability during the growth studies, surface water samples were collected from the intertidal zone to measure the amount of chlorophyll a (a frequently used proxy for phytoplankton abundance), particulate organic carbon (POC), particulate organic nitrogen $(\mathrm{PON})$, and the $\mathrm{C} / \mathrm{N}$ ratio (a measure of food quality, whereby a low $\mathrm{C} / \mathrm{N}$ ratio indicates higher quality). Water samples were collected from February through September 2000 at each site at approximately 2 wk intervals, within roughly 3 to $4 \mathrm{~d}$ of each other. Each water sample was collected from different locations within the site (separated by at least $3 \mathrm{~m}$ ), as far seaward as possible, where water was freely exchanging. Water was collected in dark bottles submerged approximately 20 to $50 \mathrm{~cm}$ below the surface (see similar methods in Menge et al. $1997 \mathrm{~b}$ and Wieters et al. 2003). For all analyses, water samples were filtered onto Whatman GF/F glass fiber filters. For chlorophyll $a, 4$ to 5 water samples were used, 200 to $600 \mathrm{ml}$ each, from each site and sample date. Chlorophyll a was measured on a Turner fluorometer (model $10 \mathrm{AU}$ ) after $24 \mathrm{~h}$ extraction in acetone, following the methods of Parsons et al. (1984). POC, PON and the $\mathrm{C} / \mathrm{N}$ ratio were all obtained from the same $\mathrm{CHN}$ analysis. For this analysis, 3 water samples (200 to $600 \mathrm{ml}$ ) were used from each site and date, using filters that had been precombusted at $450^{\circ} \mathrm{C}$ for $30 \mathrm{~min}$. After filtration, filters were dried, acid-fumed for $24 \mathrm{~h}$, and subsequently frozen at $-80^{\circ} \mathrm{C}$. Samples were analyzed within 6 to $8 \mathrm{wk}$ of collection using an organic elemental analyzer (Model CEC 440HA, Exeter Analytical) at the University of California Santa Barbara Marine Science Institute's Analytical Laboratory.

Since growth rates were measured at roughly 4 mo intervals, there were multiple fortnightly water samples associated with each growth experiment. Therefore, for each site, I used the fortnightly values from early February to early June to calculate a 'spring' mean and those from mid-May to end of September to calculate a 'summer' mean (number of sample dates for each site were 9 in spring and 11 in summer). I then examined the effect of site on each variable.

Water temperature: Temperature records were obtained from thermistors ('Tidbit' models, Onset, Bourne) suspended at depths of approximately $3 \mathrm{~m}$, within $1 \mathrm{~km}$ of shore and in close proximity to the intertidal experimental sites. The thermistors recorded temperature every 2 to $12 \mathrm{~min}$. Daily temperature averages were calculated from the high frequency samples for each site, and used to calculate a 'spring' mean temperature (early February to early June), and a 'summer' mean temperature (mid-May to end of September) for each site .

Tidal height: To judge where the 'mid-zone' of each intertidal site was in setting up the growth experiments, I used biological indicators such as the mussel zone. It is possible, however, that the mid-zone is at a different absolute tidal height at the different sites. Differences in tidal height may translate into differences in time submerged and, therefore, time for feeding. Other studies have found strong effects of tidal height on growth of intertidal organisms. Individuals lower on the shore, with longer submergence time, typically have higher growth rates than those higher on the shore (e.g. Barnes \& Powell 1953, Seed 1969). Therefore, standard surveying techniques were used to measure the absolute tide height of each experimental plot relative to mean low low water (MLLW). Because the mussel plots, gooseneck barnacle clumps and acorn barnacle plates were all at essentially the same heights at each site, only the results for the mussel plots are reported.

Upwelling: The Pacific Fisheries Environmental Laboratory (PFEL), of the National Marine Fisheries Service, maintains a database of wind speeds and directions for a series of buoys off the California coast. 
Along the California coast, winds blowing from north to south are generally upwelling favorable, so wind speeds along this axis are a reasonable proxy for upwelling (R. Mendelssohn pers. comm.). The PFEL database was used to generate daily wind speeds for February through September 2000 from a buoy in the Santa Barbara Channel $\left(34.2^{\circ} \mathrm{N}, 119.8^{\circ} \mathrm{W}\right)$, a buoy at Point Conception $\left(34.2^{\circ} \mathrm{N}, 120.7^{\circ} \mathrm{W}\right)$ and a buoy approximately offshore of Piedras Blancas $\left(35.7^{\circ} \mathrm{N}\right.$, $\left.121.9^{\circ} \mathrm{W}\right)$, to indicate the upwelling conditions in the region during the course of the study.

Statistical analyses. Analyses of covariance were used to examine the growth of mussels and barnacles, with the following factors in the models: site (fixed factor), plots/clumps/plates nested within site (random factor), and initial size as a covariate. Interactions between initial size and site, and initial size and plot (nested within site) were also included in the models. Because of differences in outplant location within sites between the seasons and methodological differences in the gooseneck barnacle experiment between seasons, spring and summer studies were analyzed separately. I also examined variation in mussel body condition (dry body weight $\times$ shell length ${ }^{-1}$ ). Because this measure of condition is standardized by size, initial size was not a factor in this model.

Stepwise regressions were used to examine the contributions of different factors to the spatial pattern of growth of mussels, gooseneck barnacles and acorn barnacles. Spring and summer were examined separately, using seasonal means from each site as the variables and a probability to enter the stepwise regression of 0.05 at each step. The possible variables were $\mathrm{POC}, \mathrm{PON}, \mathrm{C} / \mathrm{N}$ ratio, chlorophyll $a$, tidal height and water temperature. Correlations between the variables were also examined.

\section{RESULTS}

\section{Growth experiments}

Mussels. There was strong spatial variation among sites in growth for all 3 species, with growth highest at the most southern sites and decreasing to the north. For mussel growth, site, plot and initial length were all highly significant in both the spring and summer studies (Table 1). Initial length did not vary among sites or plots, and in both seasons growth rates generally decreased with increasing initial size. Post-hoc Tukey tests indicated that in the spring mussels from the 2 southernmost sites, Arroyo Hondo and Alegria, each had significantly higher growth rates (up to a maximum 4-fold difference; Fig. 2A) relative to all other sites. Among the northern sites, mussels from Cambria had significantly higher growth rates than those from Piedras Blancas and Lompoc Landing, but this difference was much smaller than the difference between southern and northern sites. In the summer, mussels from Arroyo Hondo again had higher growth rates than at all other sites, with rates nearly 6 times those of mussels at the northernmost sites. As in the spring, there was a general decrease in growth rates at more northerly sites (Fig. 2A).

Variability in mussel body condition showed similar spatial patterns to growth. In both spring and summer there were strong effects of site and plot on mussel body condition (Table 2). Mussel body condition varied nearly 3-fold among some sites (Fig. 2B). Post-hoc Tukey tests indicated that in the spring mussels from Arroyo Hondo and Alegria had significantly greater mean body conditions relative to all other sites (with Arroyo Hondo the highest of all sites), and mussels from Jalama had greater mean body condition than those from the 3 northernmost sites. In summer, posthoc Tukey tests indicated that mussels from Arroyo

Table 1. Mytilus californianus. Results of ANCOVAs examining spring and summer growth, whereby outplanted plots of mussels are nested within sites and mussel initial length is covariate

\begin{tabular}{|lrccc|}
\hline Source & df & MS & $F$ & $\mathrm{p}$ \\
\hline Spring & & & & \\
Site & 6 & 0.00655 & 9.533 & $<0.0001$ \\
Plot (site) & 18 & 0.00081 & 7.480 & $<0.0001$ \\
Initial length & 1 & 0.00104 & 9.574 & 0.0021 \\
Initial length $\times$ Site & 6 & 0.00021 & 0.328 & 0.922 \\
Initial length $\times$ Plot (site) & 18 & 0.00011 & 0.966 & 0.499 \\
Error & 335 & 0.000109 & & \\
Summer & & & & \\
Site & 6 & 0.00922 & 5.208 & 0.0018 \\
Plot (site) & 21 & 0.00213 & 11.643 & $<0.0001$ \\
Initial length & 1 & 0.00115 & 6.316 & 0.0124 \\
Initial length $\times$ Site & 6 & 0.00012 & 0.6487 & 0.6912 \\
Initial length $\times$ Plot (site) & 21 & 0.00017 & 0.928 & 0.5546 \\
Error & 384 & 0.000183 & & \\
\hline
\end{tabular}

Table 2. Mytilus californianus. Results of ANOVAs examining spring and summer body condition, whereby plots are nested within sites

\begin{tabular}{|lrccc|}
\hline Source & df & MS & $F$ & $p$ \\
\hline Spring & & & & \\
Site & 6 & 0.00184 & 55.53 & $<0.0001$ \\
Plot (site) & 18 & 0.00004 & 8.134 & $<0.0001$ \\
Error & 360 & 0.000005 & & \\
Summer & & & & \\
Site & 6 & 0.000056 & 16.22 & $<0.0001$ \\
Plot (site) & 21 & 0.00004 & 9.108 & $<0.0001$ \\
Error & 412 & 0.000004 & & \\
\hline
\end{tabular}


Table 3. Pollicipes polymerus. Results of ANCOVAs examining spring and summer growth, whereby clumps of barnacles are nested within sites and initial RC length (i.e. distance between rostral and carinal plates) is covariate

\begin{tabular}{|lrccc|}
\hline Source & df & MS & $F$ & $\mathrm{p}$ \\
\hline Spring & & & & \\
Site & 5 & 0.00045 & 109.98 & 0.7342 \\
Clump (site) & 11 & 0.00003 & 0.3234 & 0.9755 \\
Initial length & 1 & 0.00015 & 1.6056 & 0.2130 \\
Initial length $\times$ Site & 5 & 0.00002 & 0.2330 & 0.9456 \\
Initial length $\times$ Clump (site) & 11 & 0.00001 & 0.1520 & 0.9990 \\
Error & 37 & 0.000092 & & \\
Summer & & & & \\
Site & 6 & 0.00036 & 7.4027 & $<0.0001$ \\
Clump (site) & 29 & 0.00006 & 2.4071 & $<0.0001$ \\
Initial length & 1 & 0.00055 & 22.4382 & 0.0005 \\
Initial length $\times$ Site & 6 & 0.00004 & 1.5608 & 0.1651 \\
Initial length $\times$ Clump (site) & 29 & 0.00003 & 1.3652 & 0.1262 \\
Error & 113 & 0.000025 & & \\
\hline
\end{tabular}

Hondo again had the highest body condition of all the sites and those from Cambria had the lowest. Mussels from Jalama had the second-highest mean body condition, being greater than all other sites except Arroyo Hondo.

Gooseneck barnacles. For gooseneck barnacles, there were no significant differences in growth in the spring (Table 3); however due to the loss of several clumps because of marine epoxy failure, the power to detect a difference in spring was probably low. In the summer trial with larger sample sizes, site, clump and initial RC length all had highly significant effects on gooseneck barnacle growth (Table 3). The effect of size was such that, as with mussels, growth rate were lower for initially larger individuals. Post-hoc Tukey tests indicated that generally the southern sites had overall higher growth rates, being up to 4 times higher on average than the northernmost sites (Fig. 2C).

Acorn barnacles. Site was the only factor that had a significant effect on acorn barnacle growth (Table 4). Post-hoc Tukey tests indicated that, aside from Lompoc Landing (which was not significantly different from any site), acorn barnacle growth was greatest at the most southern site, Arroyo Hondo (Fig. 2D). Additionally, barnacles at Jalama had significantly higher growth rates than those at Alegria.

\section{Environmental characteristics of sites}

Food availability. Although each site did have occasional peaks in chlorophyll $a$ and POC over the entire sampling time from February through September (Fig. 3), differences in measures of food availability were not always significant among sites, or consistent
Table 4. Balanus glandula. Results of ANCOVA examining growth, whereby plates are nested within sites and initial size is covariate

\begin{tabular}{|lrccc|}
\hline Source & df & MS & $F$ & $\mathrm{p}$ \\
\hline Site & 4 & 0.00211 & 22.6066 & $<0.0001$ \\
Plate (site) & 10 & 0.00009 & 0.8528 & 0.5794 \\
Initial length & 1 & $1.48 \mathrm{e}-8$ & 0.00015 & 0.9903 \\
Initial length $\times$ Site & 4 & 0.00013 & 1.2969 & 0.2756 \\
Initial length $\times$ Plate (site) & 10 & 0.00009 & 0.9261 & 0.5122 \\
Error & 112 & 0.000101 & & \\
\hline
\end{tabular}

with each other. Chlorophyll a concentrations were generally low and similar among sites in spring $\left(F_{6,56}=\right.$ 1.57, $\mathrm{p}=0.174$, Fig. $4 \mathrm{~A})$. There was a significant borderline effect of site in summer $\left(F_{6,70}=2.28, \mathrm{p}=0.045\right)$, due to Jalama having higher chlorophyll a concentrations than Cambria. POC exhibited significant vari-
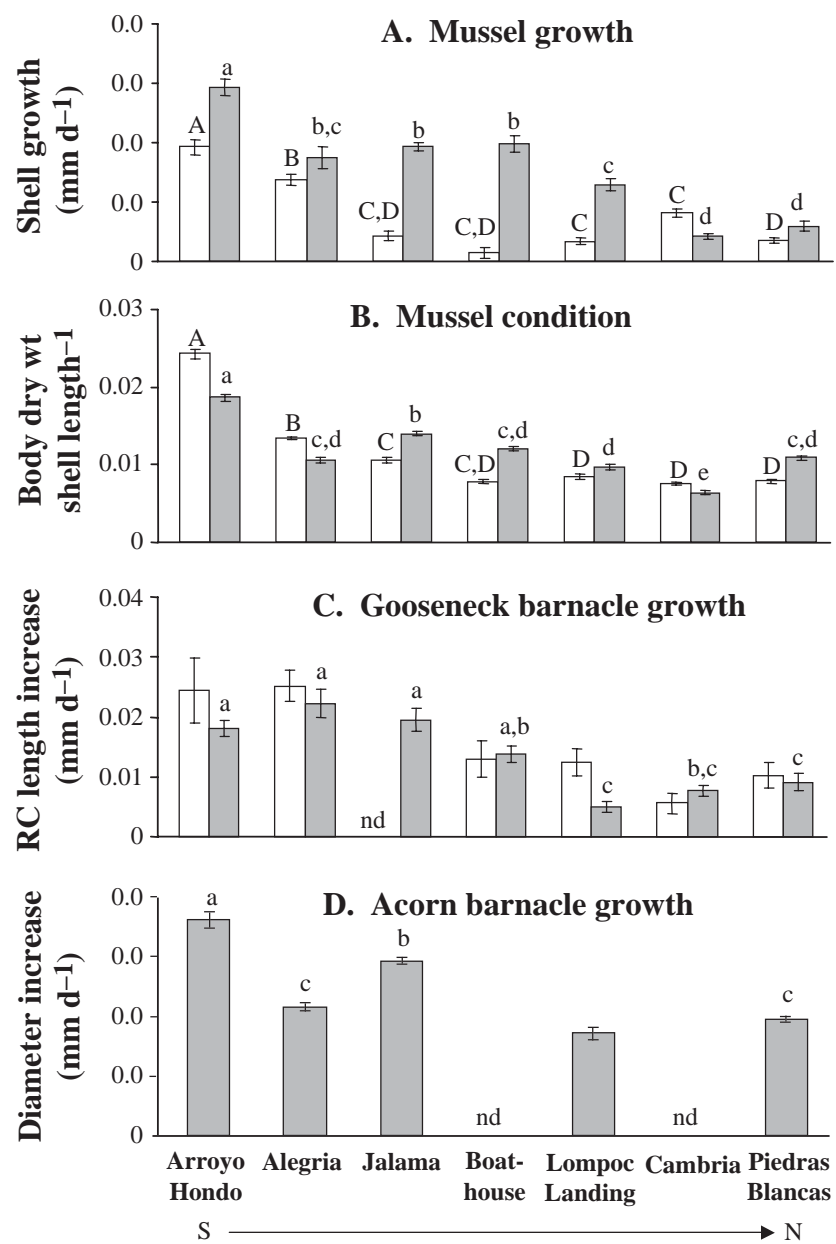

Fig. 2. (A,B) Mytilus californianus, (C) Pollicipes polymerus, (D) Balanus glandula. Growth (mean $\pm 1 \mathrm{SE}$ ) among sites. Different letters above bars indicate significantly different means (post-hoc Tukey tests; $\mathrm{p}<0.05$ ). Open bars, capital letters: spring; filled bars, lowercase letters: summer; bars for acorn barnacles show growth after $70 \mathrm{~d}$; nd: no data 


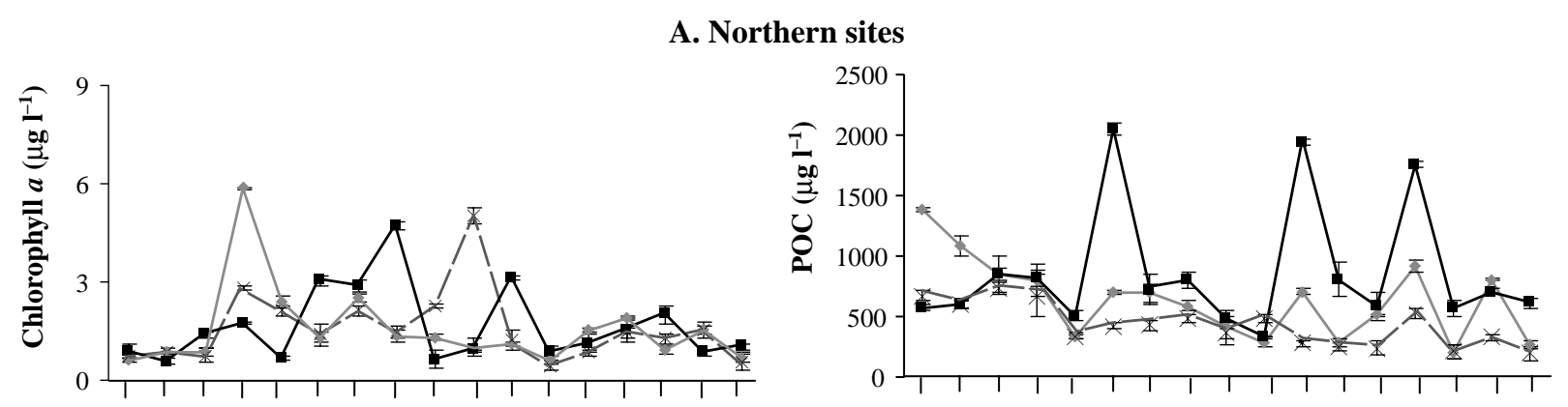

\section{B. Central sites}
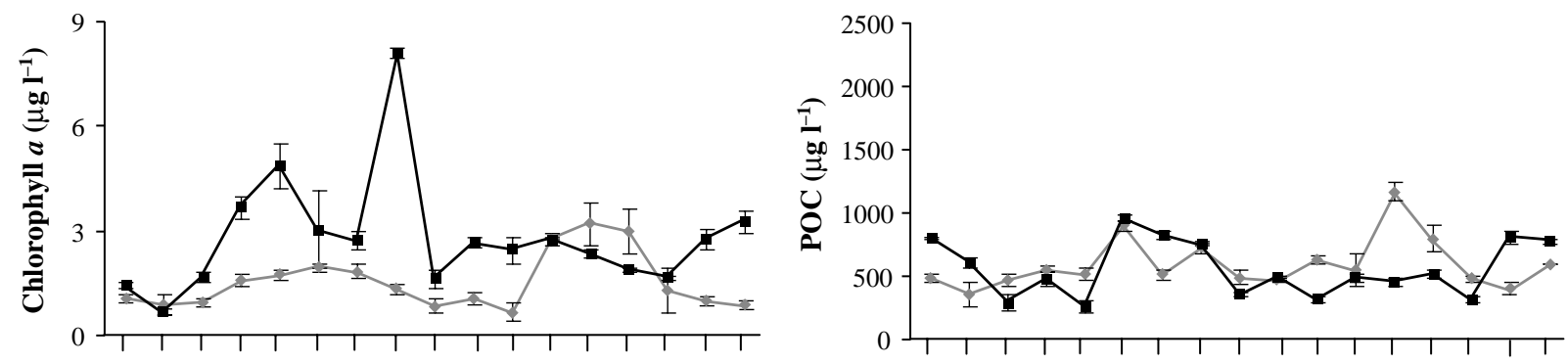

\section{Southern sites}
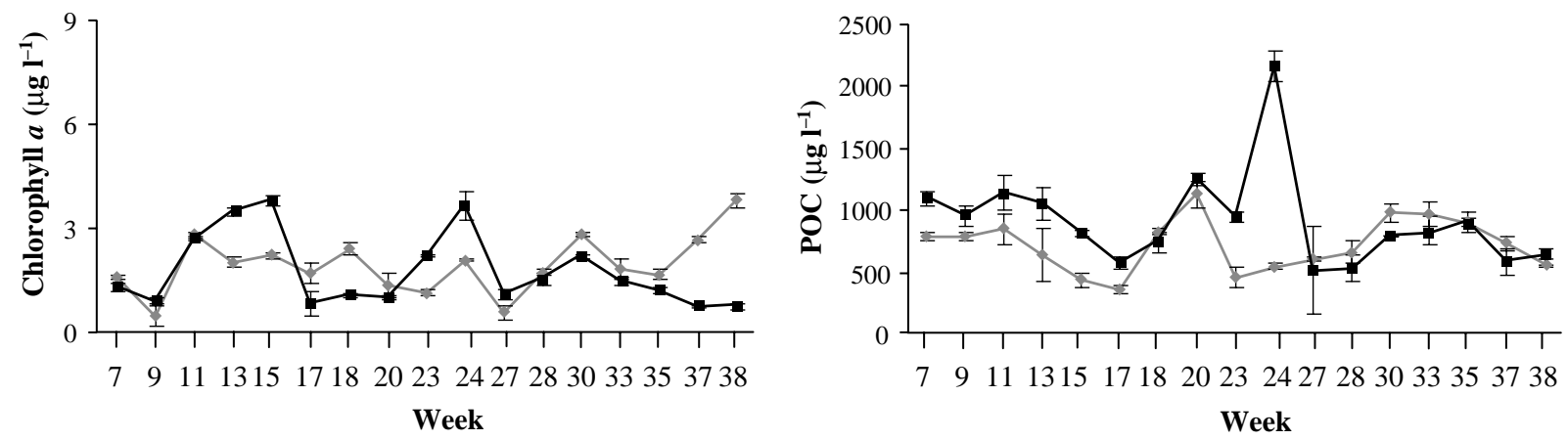

Fig. 3. Time series of mean $( \pm 1 \mathrm{SE})$ chlorophyll $a$ concentration (left-hand panels) and POC (right-hand panels) for each site for each week of 2000 in which sampling occurred. (A) For northern sites, dashed line = Piedras Blancas, gray line = Cambria, black line $=$ Lompoc Landing; $(B)$ for central sites, gray line $=$ Boathouse, black line $=$ Jalama; $(C)$ for southern sites, gray line $=$ Alegria, black line $=$ Arroyo Hondo

ability among sites in both spring $\left(F_{6,56}=2.94, \mathrm{p}=\right.$ $0.014)$ and summer $\left(F_{6,70}=4.42, \mathrm{p}=0.0008\right)$. In spring, Arroyo Hondo, the southernmost site, had nearly double the concentration of POC than the northernmost site, Piedras Blancas (Fig. 4B). In summer, Piedras Blancas had almost half the mean POC of Alegria and Lompoc Landing and almost 3 times less POC than Arroyo Hondo (Fig. 4B). PON varied little across sites with, no significant difference in the spring $\left(F_{6,56}=\right.$ 1.906, $\mathrm{p}=0.0958)$. In the summer, a significant site effect was recorded due to Lompoc Landing, which had nearly twice as much PON as Piedras Blancas (whole model $F_{6,70}=3.42, \mathrm{p}=0.0051$ ).

The $\mathrm{C} / \mathrm{N}$ ratio of the water samples differed significantly among sites only in summer (spring: $F_{6,56}=$
2.118, $\mathrm{p}=0.065 ;$ summer: $\left.F_{6,70}=10.054, \mathrm{p}<0.0001\right)$. In general, however, the direction of differences among sites ran contrary to expectations. Arroyo Hondo had a significantly higher $\mathrm{C} / \mathrm{N}$ ratio than all sites except Alegria, with a maximum difference of about $20 \%$. Alegria, in turn, had a higher mean $\mathrm{C} / \mathrm{N}$ ratio than Jalama and Piedras Blancas (about 14\% greater, Fig. 4C). Thus, 2 of the sites with the highest growth rates had the poorest quality plankton using the $\mathrm{C} / \mathrm{N}$ index.

Water temperature. Both spring and summer mean water temperatures decreased nearly monotonically from southern to northern sites (Fig. 3D). The gradients were steepest from Arroyo Hondo to Boathouse. Temperatures declined much more gradually north of Boathouse. 

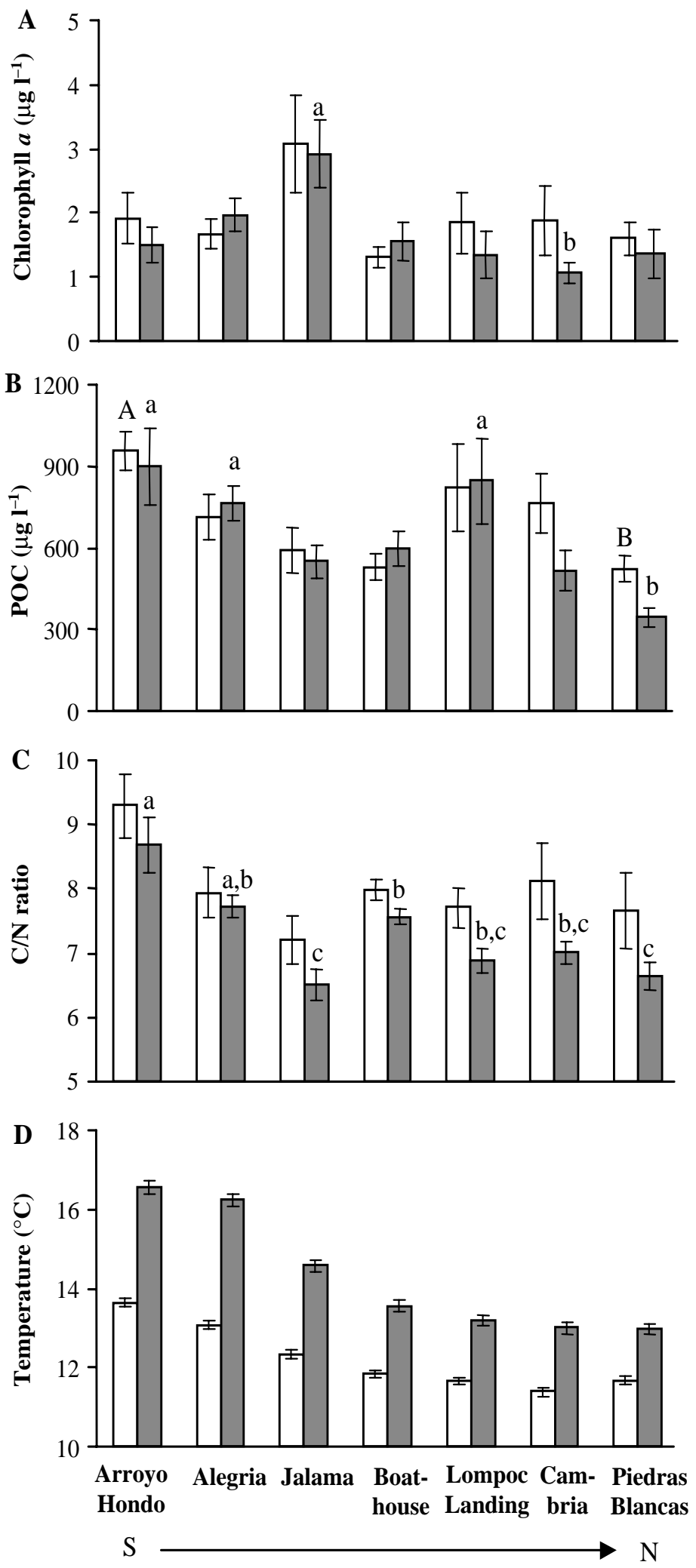

Fig. 4. Variability (mean $\pm 1 \mathrm{SE}$ ) across sites. (A to C) Planktonic food characteristics; (D) water temperature. As POC and PON showed very similar temporal and spatial trends, only results from POC are shown. Further details in Fig. 2 legend
Tidal height. There was a significant difference among sites in the absolute tidal height of the experimental mussel plots $\left(F_{6,46}=75.731, \mathrm{p}<0.0001\right)$. A posthoc Tukey test indicated that the biggest differences were that Alegria had plots lower on average than those from all other sites (at about $0.3 \mathrm{~m}$ above MLLW), and that plots at Lompoc Landing were higher than at all the other sites (about $1.8 \mathrm{~m}$ above MLLW; Fig. 5).

Upwelling. Winds favorable for upwelling occurred frequently during the course of the study, from Point Conception to the north, with several extended periods of large negative values (indicating strong winds blowing from north to south), especially in the summer (Fig. 6). The buoy for the Santa Barbara Channel however indicated weaker winds frequently blowing in a direction unfavorable for upwelling (i.e. south to north). Water samples were taken over a variety of conditions (Fig. 6), including when winds in the north were favorable for upwelling and when they were not.

\section{Stepwise multiple regressions to explain filter-feeder growth}

Water temperature was consistently selected by the stepwise procedure and incorporated into models to explain mussel and gooseneck barnacle growth (Table 5). For the summer these results are difficult to interpret because temperature was correlated with the tidal height of the mussel plots; however this was not the case in spring. In spring, water temperature was positively correlated with mussel and gooseneck barnacle growth, as well as mussel condition, such that sites with higher mean water temperature had greater biological responses. For gooseneck barnacle growth, the $\mathrm{C} / \mathrm{N}$ ratio was also a significant factor. The direction of the $\mathrm{C} / \mathrm{N}$ correlations, however, was opposite to what would be expected based on food quality (i.e.

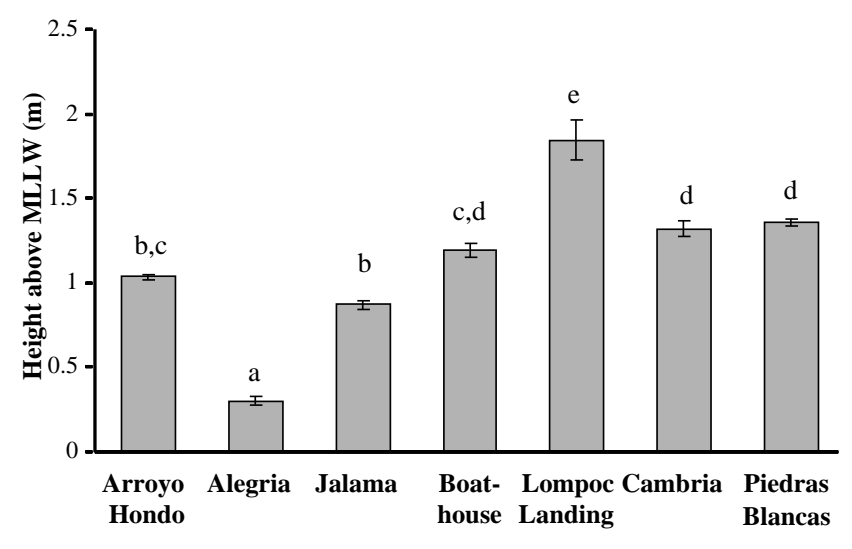

Fig. 5. Tidal height (mean \pm 1 SE) of experimental mussel plots in mid-zone of each site 


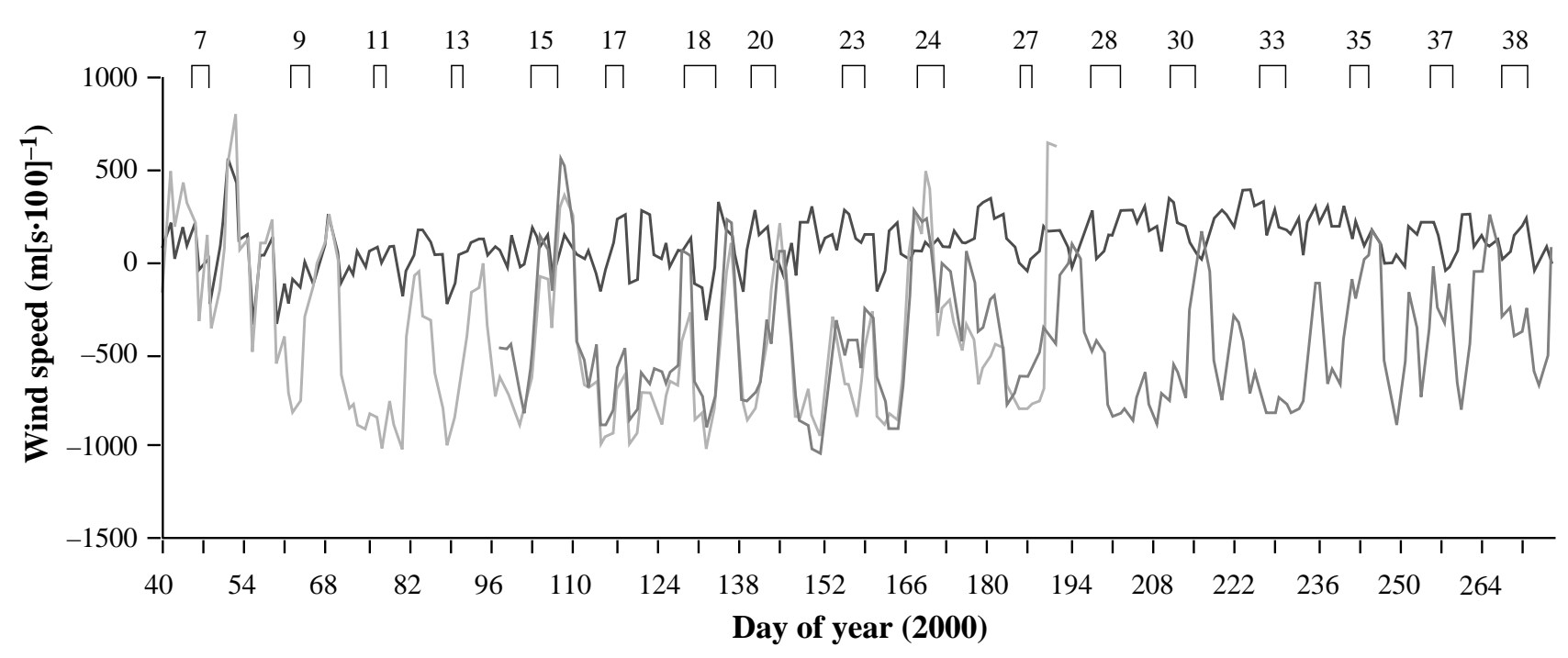

Fig. 6. Daily north-south component of wind speed at 3 NOAA buoys located in study region during course of this study. Upwelling favorable winds are from north to south (negative values). Locations of the buoys are in Santa Barbara Channel (black line), Point Conception (light gray line), and offshore of Piedras Blancas (dark gray line). Brackets above lines: dates during which water samples were taken from intertidal sites, with week of sampling indicated above each

growth/condition was higher at sites with higher $\mathrm{C} / \mathrm{N}$ ratios).

No significant models were selected for mussel body condition or acorn barnacle growth in summer. Water temperature was again selected for mussel growth as well as gooseneck barnacle growth in summer. In addition, 2 other factors - tidal height and chlorophyll a-were selected in the model for gooseneck barnacle growth. However, in the summer, tidal height was significantly negatively correlated with temperature ( $p=0.036, r=-0.79$ ), i.e. sites with higher midzones had cooler water temperatures. POC and PON were highly positively correlated with each other in both spring $(\mathrm{p}=0.003, \mathrm{r}=0.93)$ and summer $(\mathrm{p}=0.004$, $\mathrm{r}=0.92)$.

\section{DISCUSSION}

All 3 species of filter-feeders examined here showed a striking geographic pattern of growth. Contrary to predictions, growth rates at sites south of Point Conception were relatively high, and declined moving around the Point and to the north. Of particular interest is the fact that, again contrary to predictions, this geographical pattern seems largely unrelated to any corresponding variability in food supply as measured by amounts of chlorophyll $a$, POC, or PON. In other studies, differences in planktonic food supply using these measures have been found to influence benthic filter-feeder growth profoundly. Menge (1992) and Menge et al. $(1997 \mathrm{a}, \mathrm{b})$ reported that at a site where intertidal chlorophyll a was consistently higher, filterfeeders were more abundant and had higher growth rates than at a neighboring site where chlorophyll a was lower. Bertness et al. (1991) reported similar findings for the North Atlantic barnacle Semibalanus balanoides. Sites with higher chlorophyll a and higher wave velocities had much higher growth rates, and local and regional patterns in growth were predictable outcomes of food supply rates.

Table 5. Mytilus californianus and Pollicipes polymerus. Explanatory power of physical variables at each site for filterfeeder growth (only significant models shown). Shown are parameters chosen by stepwise procedure, their associated $\mathrm{R}^{2}$ and $\mathrm{p}$-values in final model; $\mathrm{R}^{2}$ and $\mathrm{p}$ values associated with each variable alone are given in parentheses

\begin{tabular}{|llcc|}
\hline $\begin{array}{l}\text { Dependent } \\
\text { variable }\end{array}$ & $\begin{array}{l}\text { Independent } \\
\text { variable }\end{array}$ & $\mathrm{R}^{2}$ & $\mathrm{p}$ \\
\hline SPRING & & & \\
Mussel & & & \\
$\quad$ Shell growth & Temperature & 0.71 & 0.0171 \\
$\quad$ Condition & Temperature & 0.828 & 0.0045 \\
Gooseneck barnacle & & & \\
$\quad$ Growth & Temperature & $(0.911)$ & $0.0011(0.003)$ \\
& C/N ratio & $(0.287)$ & $0.0252(0.274)$ \\
SuMMER & Model & 0.987 & 0.0015 \\
Mussel & & & \\
$\quad$ Shell growth & Temperature & 0.587 & 0.045 \\
Gooseneck barnacle & & & \\
Growth & Tidal height & $(0.756)$ & $0.0151(0.011)$ \\
& Temperature & $(0.756)$ & $0.0051(0.011)$ \\
& Chlorophyll $a$ & $(0.493)$ & $0.0388(0.0787)$ \\
& Model & 0.990 & 0.0017 \\
\hline
\end{tabular}


Surprisingly, in this study, although there was large variation in growth rates across sites, there was no corresponding large variation in the overall food supply using these aggregate measures. On the contrary, although there were occasional peaks in chlorophyll at most sites, on average it was consistently low across the whole region. POC did not vary substantially or consistently either. It is possible that the approximately fortnightly sampling scheme used was not frequent enough to detect differences in chlorophyll a across sites, as blooms can occur and dissipate again in less than 1 wk (Wieters et al. 2003). The question remains open however, as to how many short-lived pulses of phytoplankton or particulates (that may have been missed in the sampling) would be required to result in such large differences in growth. Further, to account for the patterns of growth found here would require higher phytoplankton and/or particulates at the southern sites, particularly Arroyo Hondo, and again this is opposite to what was predicted.

Other studies measuring phytoplankton biomass from intertidal stations have produced conflicting results, with some demonstrating large differences among sites (i.e. a site in an upwelling region with higher chlorophyll a than a neighboring site outside, e.g. Menge et al. 1997b) even with less frequent sampling; others demonstrating low chlorophyll $a$ on- or nearshore, even in upwelling regions where relatively high levels of chlorophyll a occur further offshore (Cliff 1982a,b, Demers et al. 1989). It is not uncommon to find low nearshore phytoplankton biomass in areas of active upwelling, as it can take up to several days for blooms to grow in response to the increased nutrients (Field et al. 1980, Barlow 1982, Brown \& Field 1986, Peterson et al. 1988, Wieters et al. 2003). This may be similar to the situation in the region north of Point Conception, where persistent upwelling results in planktonic production developing well offshore (e.g. Abbott \& Zion 1985). If blooms are transported away by currents, this enhanced production might rarely become available to coastal benthic organisms in this region. Dugdale \& Wilkerson (1989) argued that strong upwelling and resultant offshore advection does in fact lead to the low chlorophyll $a$ they found in the nearshore environment between Points Conception and Arguello. A similar argument has been put forth to explain low barnacle settlement in the intertidal of central California, i.e. that strong, persistent upwelling does not allow as many planktonic larvae to return to shore compared to periods or regions where relaxation events occur frequently (Roughgarden et al. 1988, 1991). Thus, the potential for coastal upwelling to influence benthic organisms is likely to depend on the degree to which upwelling is persistent vs. variable; and also on the circulation patterns in the region, which determine where/when phytoplankton blooms resulting from upwelling are likely to be delivered to the shore. What was unexpected in this study was not necessarily that there was low phytoplankton biomass nearshore across the region, but that there was nonetheless a strong spatial pattern of growth for multiple species of filter-feeders.

Variation among sites in absolute amounts of planktonic food was not extensive and did not provide strong explanatory power for the patterns of growth. Neither was tidal height sufficient to account for these patterns of growth, although it did vary across sites and cannot be completely discounted as a potentially important influence. Instead, water temperature was the only site characteristic that varied in a manner consistent with the spatial patterns of growth. Southern sites, where growth was higher, had warmer water temperatures. Water temperature differences in this region are principally due to large-scale circulation patterns and have been documented extensively: north of Point Conception the dominating flow is that of the southward moving cold, subarctic waters of the California Current; circulation in the Southern California Bight on the other hand is largely dominated by the poleward flow of warmer, equatorial waters in the Southern California Countercurrent (Hickey 1993).

In general, it is expected that rates of growth of marine invertebrates should increase with a rise in temperature over a species' range (e.g. Newell 1979). For Mytilus californianus, Coe \& Fox (1944) found that the most rapid mussel growth rates occurred between 17 and $20^{\circ} \mathrm{C}$, while growth rates were slower below $14^{\circ} \mathrm{C}$. This is very similar to the range of temperatures in this study and supports the current findings. In laboratory experiments, Bayne et al. (1976) found that M. californianus had an increasing, positive scope for growth with increasing temperatures between 13 and $17.5^{\circ} \mathrm{C}$ and that filtration rate increased with increasing temperature, with a $Q_{10}$ greater than 1.8 over this same temperature range.

Cirral activity increases with increasing temperature for barnacles as well (Southward 1955, 1957), leading Crisp \& Bourget (1985) to state that in general temperature should enhance growth rates of barnacles. Sanford \& Menge (2001) examined barnacle growth in a region of coastal upwelling, and also suggested that the increase of barnacle growth with increasing temperature could account for some of the limits of their explanations based on food supply alone.

It is also possible, however, that water temperature is correlated with other factors not reported in this study that may contribute to this geographic pattern in growth of these 3 different species of filter-feeders. For example, composition of the plankton may vary spatially and may also play a role in influencing patterns of 
growth. This will be examined in future work. Additionally, wave exposure varies geographically, generally increasing from south to north around Point Conception (Blanchette et al. 2002). However, mussel and barnacle growth tends to increasing with increased wave exposure or water velocity (Moore 1934, Crisp 1960, Bertness et al. 1991, Steffani \& Branch 2003), at least up to a point. It is not known whether wave exposure at the time of these experiments was extreme enough to account for the decreased growth seen at the generally more wave-exposed northern sites. As pointed out by many authors examining factors that influence the growth of mussels or barnacles in the field (e.g. Barnes \& Barnes 1959a,b, Crisp \& Bourget 1985, Seed \& Suchanek 1992), it is difficult to disentangle the relative importance of different factors that influence growth in natural populations, especially when they covary or may affect growth synergistically. What is unique about this region is that in the absence of a clear difference in planktonic food supply (often stated to be the primary driver of differences in growth) a geographical gradient in differential growth is still evident.

Even without being able to isolate the underlying cause, there is clear evidence for a dramatic geographic gradient in growth rates for several species of common and abundant benthic filter-feeders. Moreover, this gradient runs counter to predictions based on studies in other regions on the effects upwelling may have on adult filter-feeders. Filter-feeder growth rates are dramatically higher where upwelling is weakest. This pattern may potentially have an important effect on community dynamics across this region. There is also evidence that large increases in nutrients are associated with the persistent upwelling north of Point Conception, and these high nutrients appear to enhance the success of seaweeds (Blanchette et al. 2002). Indeed, in contrast to the pattern seen in filter-feeders, seaweeds perform better at northern sites and worse at sites to the south of Point Conception (Blanchette et al. 2002). Increased performance of seaweeds, concomitant with decreased performance of filter-feeders, may shift the relative dominance of these groups in communities across this region (i.e. from filter-feeder-dominated at southern sites to seaweed-dominated at northern sites).

Acknowledgements. I would like to thank the following people: C. Galst, M. Meyers, N. Hernandez, C. McGary and M. Durham for generous field and laboratory help; C. Svedlund and C. Blanchette for logistical support in the field. This research was supported by funds from a National Science Foundation graduate fellowship to the author, also in part by NSF BIR94-13141 and NSF GER93-54870 to W. Murdoch. This manuscript greatly benefited by the comments of $\mathrm{S}$. Gaines, R. Warner, and A. Alldredge and 3 anonymous reviewers. This is contribution number 171 from PISCO: the Partnership for the Interdisciplinary Study of Coastal Oceans,
A Long-Term Ecological Consortium, funded by the David and Lucile Packard Foundation.

\section{LITERATURE CITED}

Abbott MR, Zion PM (1985) Satellite observations of phytoplankton variability during an upwelling event. Cont Shelf Res 4:661-680

Atkinson LP, Brink KH, Davis RE, Jones BH, Palusczkiewicz T, Stuart DW (1986) Mesoscale hydrographic variability in the vicinity of Points Conception and Arguello during April-May 1983: the OPUS 1983 experiment. J Geophys Res 91:12899-12918

Barlow RG (1982) Phytoplankton ecology in the Southern Benguela Current. III. Dynamics of a bloom. J Exp Mar Biol Ecol 63:239-248

Barnes H, Barnes M (1959a) Some parameters of growth in the common intertidal barnacle Balanus balanoides (L.). J Mar Biol Assoc UK 38:581-587

Barnes H, Barnes M (1959b) A comparison of the annual growth patterns of Balanus balanoides (L.) with particular reference to the effect of food and temperature. Oikos 10:1-18

Barnes H, Powell HT (1953) The growth of Balanus balanoides (L.) and B. crenatus Brug. under varying conditions of submersion. J Mar Biol Assoc UK 32:107-128

Bayne BL, Bayne CJ, Carefoot TC, Thompson RJ (1976) The physiological ecology of Mytilus californianus Conrad I. Metabolism and energy balance. Oecologia 22:211-228

Bertness MD, Gaines S, Bermudez D, Sanford E (1991) Extreme spatial variation in the growth and reproductive output of the acorn barnacle Semibalanus balanoides. Mar Ecol Prog Ser 75:91-100

Blanchette CA, Miner, BG, Gaines SD (2002) Geographic variability in form, size and survival of Egregia menziesii around Point Conception, California. Mar Ecol Prog Ser 239:69-82

Brink KH, Chausse D, Davis RE (1984) Observation of the coastal upwelling region near $34^{\circ} 30^{\prime} \mathrm{N}$ off California: spring 1981. J Phys Oceanogr 14:378-391

Broitman BR, Navarette SA, Smith F, Gaines SD (2001) Geographic variation of southeastern Pacific intertidal communities. Mar Ecol Prog Ser 224:21-34

Brown PC, Field JG (1986) Factors limiting phytoplankton production in a nearshore upwelling area. J Plankton Res 8:55-68

Buss LW (1986) Competition and community organization on hard surfaces in the sea. In: Diamond J, Case TJ (eds) Community ecology. Harper \& Row, New York, p 517-536

Bustamante RH, Branch GM, Eekhout S, Robertson B and 7 others (1995) Gradients of intertidal primary productivity around the coast of South Africa and their relationships with consumer biomass. Oecologia 102:189-201

Cliff G (1982a) Seasonal variation in the contribution of phytoplankton, bacteria and inorganic nutrients to a rocky shore ecosystem. Trans R Soc S Afr 44:523-539

Cliff G (1982b) Dissolved and particulate matter in the surface waters of False Bay and its influence on a rocky shore ecosystem. Trans R Soc S Afr 44:539-549

Coe WR, Fox DL (1944) Biology of the California sea-mussel (Mytilus californianus). III. Environmental conditions and rate of growth. J Exp Zool 94:59-71

Connell JH (1972) Community interaction on marine rocky intertidal shores. Annu Rev Ecol Syst 3:169-192

Crisp DJ (1960) Factors influencing growth rate in Balanus balanoides. J Anim Ecol 29:95-116 
Crisp DJ, Bourget E (1985) Growth in barnacles. Adv Mar Biol 22:199-244

Demers S, Therriault JC, Bourget E, Desilets H (1989) Smallscale gradients of phytoplankton productivity in the littoral fringe. Mar Biol 100:393-399

Dugdale RC, Wilkerson FP (1989) New production in the upwelling center at Point Conception, California: temporal and spatial patterns. Deep-Sea Res 36:985-1007

Field JG, Griffiths CL, Linley EA, Carter RA, Zoutendyk P (1980) Upwelling in a nearshore marine ecosystem and its biological implications. Estuar Coast Shelf Sci 11:133-150

Hickey BM (1993) Physical oceanography. In: Dailey MD, Anderson JW, Reish DJ, Gorsline DS (eds) Ecology of the Southern California Bight: a synthesis and interpretation. University of California Press, Berkeley, CA, p 19-70

Lewis CA, Chia FS (1981) Growth, fecundity, and reproductive biology in the pedunculate cirripede Pollicipes polymerus at San Juan Island, Washington. Can J Zool 59: 893-901

Lewis JR (1964) The ecology of rocky shores. English Universities Press, London

Menge BA (1992) Community regulation: under what conditions are bottom-up factors important on rocky shores. Ecology 73:755-765

Menge BA (2000) Top-down and bottom-up community regulation in marine rocky intertidal habitats. J Exp Mar Biol Ecol 250:257-289

Menge BA, Daley BA, Wheeler PA, Dahlhoff E, Sanford E, Straub PT (1997a) Benthic-pelagic links and rocky intertidal communities: bottom-up effects on top-down control? Proc Natl Acad Sci USA 94:14530-14535

Menge BA, Daley BA, Wheeler PA, Straub PT (1997b) Rocky intertidal oceanography: an association between community structure and nearshore phytoplankton concentration. Limnol Oceanogr 42:57-66

Moore HB (1934) The biology of Balanus balanoides. I. Growth rate and its relation to size, season and tidal level. J Mar Biol Assoc UK 19:851-868

Newell RC (1979) Biology of intertidal animals. Marine Ecological Surveys, Faversham

Paine RT (1974) Intertidal community structure, experimental studies on the relationship between a dominant competitor and its principal predator. Oecologia 15:93-120

Paine RT (1976) Size-limited predation: an observational and experimental approach with the Mytilus-Pisaster interaction. Ecology 57:858-873

Parsons TR, Maita Y, Lalli CM (1984) A manual of chemical and biological methods of seawater analysis. Pergamon Press, New York

Pelaez J, McGowan JA (1986) Phytoplankton pigment pat-

Editorial responsibility: Otto Kinne (Editor-in-Chief), Oldendorf/Luhe, Germany terns in the California (USA) current as determined by satellite. Limnol Oceanogr 31:927-950

Peterson WT, Arcos DF, McManus GB, Dam H, Bellatoni D, Johnson T, Tiselius $P$ (1988) The nearshore zone during coastal upwelling: daily variability and coupling between primary and secondary production off Central Chile. Prog Oceanogr 20:1-40

Roughgarden J, Gaines S, Possingham H (1988) Recruitment dynamics in complex life cycles. Science 241:1460-1461

Roughgarden J, Pennington JT, Stoner D, Alexander S, Miller K (1991) Collisions of upwelling fronts with the intertidal zone: the cause of recruitment pulses in barnacle populations of central California (USA). Acta Oecol 12:35-52

Sanford E, Menge BA (2001) Spatial and temporal variation in barnacle growth in a coastal upwelling system. Mar Ecol Prog Ser 209:143-157

Seed R (1969) The ecology of Mytilus edulis L. (Lamellibranchiata) of exposed rocky shores. II. Growth and mortality. Oecologia 3:317-350

Seed R, Suchanek TH (1992) Population and community ecology of Mytilus. In: Gosling E (ed) The mussel Mytilus: ecology, physiology, genetics and culture. Elsevier, Amsterdam, p 87-168

Shanks AL, Largier J, Brink L, Brubaker J, Hooff R (2000) Demonstration of the onshore transport of larval invertebrates by the shoreward movement of an upwelling front. Limnol Oceanogr 45:230-236

Southward AJ (1955) On the behaviour of barnacles. I. The relation of cirral and other activities to temperature. J Mar Biol Assoc UK 34:403-422

Southward AJ (1957) On the behaviour of barnacles. III. Further observations on the influence of temperature and age on cirral activity. J Mar Biol Assoc UK 36:323-334

Steffani CN, Branch GM (2003) Growth rate, condition and shell shape of Mytilus galloprovincialis: responses to wave exposure. Mar Ecol Prog Ser 246:197-209

Stephenson TA, Stephenson A (1972) Life between tidemarks on rocky shores. Freeman, San Francisco, CA

Sverdrup HU (1938) On the process of upwelling. J Mar Res 2:155-164

Vermeij GJ (1971) Temperature relationships of some tropical Pacific intertidal gastropods. Mar Biol 10:308-314

Wieters EA, Kaplan DM, Navarette SA, Sotomayor A, Largier JL, Nielsen KJ, Veliz F (2003) Alongshore and temporal variability in chlorophyll a concentration in Chilean nearshore waters. Mar Ecol Prog Ser 249:93-105

Wing SR, Botsford LW, Largier JL, Morgan LE (1995) Spatial structure of relaxation events and crab settlement in the northern California upwelling system. Mar Ecol Prog Ser 128:199-211

Submitted: June 29, 2004; Accepted: February 3, 2005

Proofs received from author(s): May 31, 2005 